\title{
The Hoover Mennonites in Belize: A History of Expansion in the Shadow of Separation
}

\author{
Carel Roessingh \\ Associate Professor \\ Faculty of Social Sciences, Department of Organization Sciences \\ Vrije Universiteit Amsterdam \\ Daniëlle Bovenberg \\ Doctoral candidate \\ Technology Management Program \\ University of California, Santa Barbara
}

\begin{abstract}
We examine the migration history of the Old Order Hoover Mennonites located in the small, multiethnic country of Belize. The Hoover Mennonites live in the settlements of Upper Barton Creek, Springfield, Birdwalk, and Roseville. Characterized as one of Belize's more conservative churches, the Hoover Church is also Belize's most geographically dispersed Mennonite community. This paper brings together historical and present-day sources to account for and chart this dispersion. To describe what brought together this group between 1958 and 1984 and what drove their subsequent migration across Belize, we examine the religious and legal circumstances of the founding of their settlements. Observations and reflections on their most recent expansion consider how changes in immigration policy, desire for separation from worldly influences, and population growth contributed to an Old Order community that is doubly separated: from the world and from kindred settlements.
\end{abstract}

\section{Keywords}

Hoover Mennonites; Belize; Old Order Mennonites; Noah Hoover Church; Expansion; Migration

\section{Acknowledgements}

The authors would like to thank Piet Visser for his comments on an earlier draft. The first author would like to thank members of the Hoover Mennonite communities mentioned in this article for their hospitality and kindness. The authors also thank Cory Anderson for careful comments on earlier drafts. 


\section{Introduction: Driving into Belize}

Those who visit Belize by road today will likely enter across its Mexican border, on a road that runs from the flat and swampy delta across the border towards the capital of Belize, Belmopan, situated in hilly jungle, where the road turns west towards Guatemala. The road, today taken by many visitors to the small country, corresponds roughly to the route taken in 1958 by a group of Mennonites first entering Belize, or British Honduras as it was called at the time. Their trip through this diverse terrain was not so quick, nor so easy, as eyewitness accounts attest (Koop 1991; Penner, et al. 2008). Despite initial "hardships," these men and women remained, and their number grew to what is today a stable and variegated presence in Belize. Already a multi-ethnic country (Bolland 1986; Roessingh and Plasil 2009), Belize is home to several Mennonite denominations. These groups entered Belize at different moments in history. When asked about their present-day composition, members will refer to a hard-won path into Belize, a search for land, population growth, and a commitment to a "separation from the world," which sometimes leads to ecclesiastical schism: the choice to separate from a settlement to start one's own, based on a stricter interpretation of Scripture. Yet settlement patterns vary widely among these groups, and it is these variations that are our point of departure.

In this article, we trace the migration history of the Old Order Noah Hoover Mennonites. ${ }^{1}$ Often characterized as one of the more conservative churches in Belize (Scott 1996; Anderson 2013), they are also one of the country's most geographically dispersed Mennonite communities. Unlike other denominations, whose people live in large colonies of up to 600 families, the Hoover Mennonites live in small settlements of no more than 30 families. Moreover, their settlements are located more than half a day's buggy ride apart from each other. This different settlement pattern, we argue, can be traced back to circumstances specific to the denomination and the historical context of its formation.

First, the Old Order Mennonites share a desire for and a strict interpretation of separation from the world, along with a willingness to move when this separation becomes untenable. Second, when the predecessors of the Hoover Mennonites built their first settlement in 1969, they met conditions from the Belizean government that effectively limited their ability to buy large plots of land adjacent to their settlement. Steady growth within the Hoover community nevertheless made the need for more land a reality. Third, for reasons of internal unity, they express a preference to keep their communities below 35 families. For various reasons throughout their history, then, Hoover Mennonites have chosen to start settlements farther afield, their most recent settlement having been established in 2012. The history of this group in Belize has not yet been documented, and it is to this history that this article makes a contribution.

We start this paper by introducing a number of concepts and issues in the Belizean context relevant to our narrative: Belize's history with Mennonite immigration and the different historical reasons for migration within the country. Having the Hoover Mennonites in focus, starting from their harrowing entry into Belize, we describe the circumstances that marked the 
founding of their first settlement in Upper Barton Creek and their fellowship and formal affiliation with the Old Order Mennonites of the Noah Hoover Church in Scottsville, Kentucky. Then we discuss the founding of the settlements of Springfield, Birdwalk, and Roseville in Belize. We supplement this historical survey with recent descriptions from the field, collected by the first author. We aim to show how a change in government policy by the Belizean government, a desire for separation from the world, and demographic growth contributed to a Hoover Mennonite community that is doubly separated, from the world and from each other, as a commitment to small communities and the search for good farming land stimulates them to travel far for their continued expansion.

\section{Who Are the Mennonites of Belize?}

Belize is home to approximately 12,000 Mennonites, religious descendants of the Dutch Catholic Priest turned Anabaptist leader, Menno Simons (1496-1561). Today, most of the Mennonite settlements in Belize are based in the agricultural economy (Everitt 1983; Roessingh 2007). The first arrivals in Belize were the Old Colony and Kleine Gemeinde Mennonites, who arrived in 1958. They share Dutch, Prussian, and Russian roots and the language of Plautdietsch. The Old Colony soon split into a group in Blue Creek, which became the more lenient Evangelical Mennonite Mission Conference (EMMC), and a stricter group in Shipyard, still Old Colony. Later arrivals were the Old Order Mennonites and Amish (Anderson and Anderson 2016), conversant in Pennsylvania Dutch and having South-German / Swiss lineage. This migration contained the seeds of the Hoover Mennonites.

As we will discuss, the Belizean government amended the settlement conditions for those arriving after 1966. This is not the first time a regulatory change has interfered with Anabaptist migration efforts (Luthy 1997, 10-12). The group settling under the 1958 conditions was allowed to keep closed colonies, essentially enclaves within Belizean society. Those arriving in 1966 under the new conditions were not: Belizeans were allowed to settle within Mennonite communities, preventing the isolation available to earlier settlements.

One motive for geographical separation among Mennonites has historically been religious difference. Stories of the expansion of Mennonites in Belize are also often also tales of chosen separation of a community's most conservative members (Sawatzky 1971). The more progressive Mennonite communities and settlements in Belize are those that stay put geographically, and in time accept the use of (more) modern equipment, including agricultural machinery, telephones, and computers.

Originally hailing from different Mennonite denominations with their unique paths into Belize, one set of families found common ground in the 1960s in their search for a satisfactory separation from the world: they would go on to form the Hoover Mennonites (Friesen 1989, 900). Over time, different families, sometimes from outside Belize, have joined the Old Order Mennonite community, and most of these Mennonites had separated themselves at various 
Table 1. Inhabitants of Mennonite Settlements in Belize

\begin{tabular}{lccccc}
\hline Inhabitants & Total & Men & Women & $\begin{array}{c}\text { Total } \\
\text { households in } \\
\text { settlement }\end{array}$ & $\begin{array}{c}\text { Avgerage } \\
\text { household } \\
\text { size }\end{array}$ \\
\hline Country total & 322,453 & 161,227 & 161,226 & & 4.1 \\
\hline Mennonites (ethnic) & 11,574 & 5,470 & 5,604 & & \\
Mennonites (church)* & 12,053 & 6,076 & 5,977 & & \\
\hline
\end{tabular}

Cayo district

4.4

Church: Old Order Noah Hoover Mennonites

$\begin{array}{llllcl}\text { Upper Barton Creek } & 380 & 201 & 179 & 54(27)^{* *} & 6.8 \\ \text { Springfield } & 270 & 133 & 137 & 40 & 7.0\end{array}$

Church: Old Colony/Old Order Mennonites

$\begin{array}{llllll}\text { Lower Barton Creek } & 193 & 110 & 83 & 30 \text { (54)** } & 6.4\end{array}$

Church: Kleine Gemeinde/Evangelical Mennonite Mission Conference (EMMC)

$\begin{array}{llllll}\text { Spanish Lookout } & 2,253 & 1,151 & 1,102 & 482 & 4.7\end{array}$

$\begin{array}{ll}\text { Corozal district } & 4.4\end{array}$

Church: Old Colony

$\begin{array}{llllll}\text { Little Belize } & 2,650 & 1,346 & 1,304 & 427 & 6.2\end{array}$

Orange Walk district

4.4

Church: Old Colony/EMMC

$\begin{array}{llllll}\text { Shipyard } & 3,345 & 1,706 & 1,639 & 621 & 5.4\end{array}$

Church: Old Colony

$\begin{array}{llllll}\text { Indian Creek } & 904 & 468 & 436 & 150 & 6.0\end{array}$

Church: EMMC/Kleine Gemeinde

Blue Creek

407

$217 \quad 190$

111

3.7

*Ethnic Mennonites share a common descent from Europe, especially the Netherlands, Switzerland and Germany, as well as shared assumptions and morals. Members of the Mennonite church, however, do not necessarily have to share an ethnic background. Therefore, the number of 'church' Mennonites is larger.

**Talks between the first author in May 2017 and bishop and land commissioner of Springfield revealed that the settlements of Upper Barton Creek and Lower Barton Creek contain respectively 27 and 54 families. They further indicated that Birdwalk houses about twelve households and Roseville seventeen. Birdwalk and Roseville settlements are so recent that they do not yet appear in government census data. Source: Statistical Institute of Belize (2013) 


\section{Figure 1: Mennonite Settlements with Year of Founding and Major Cities in Belize}

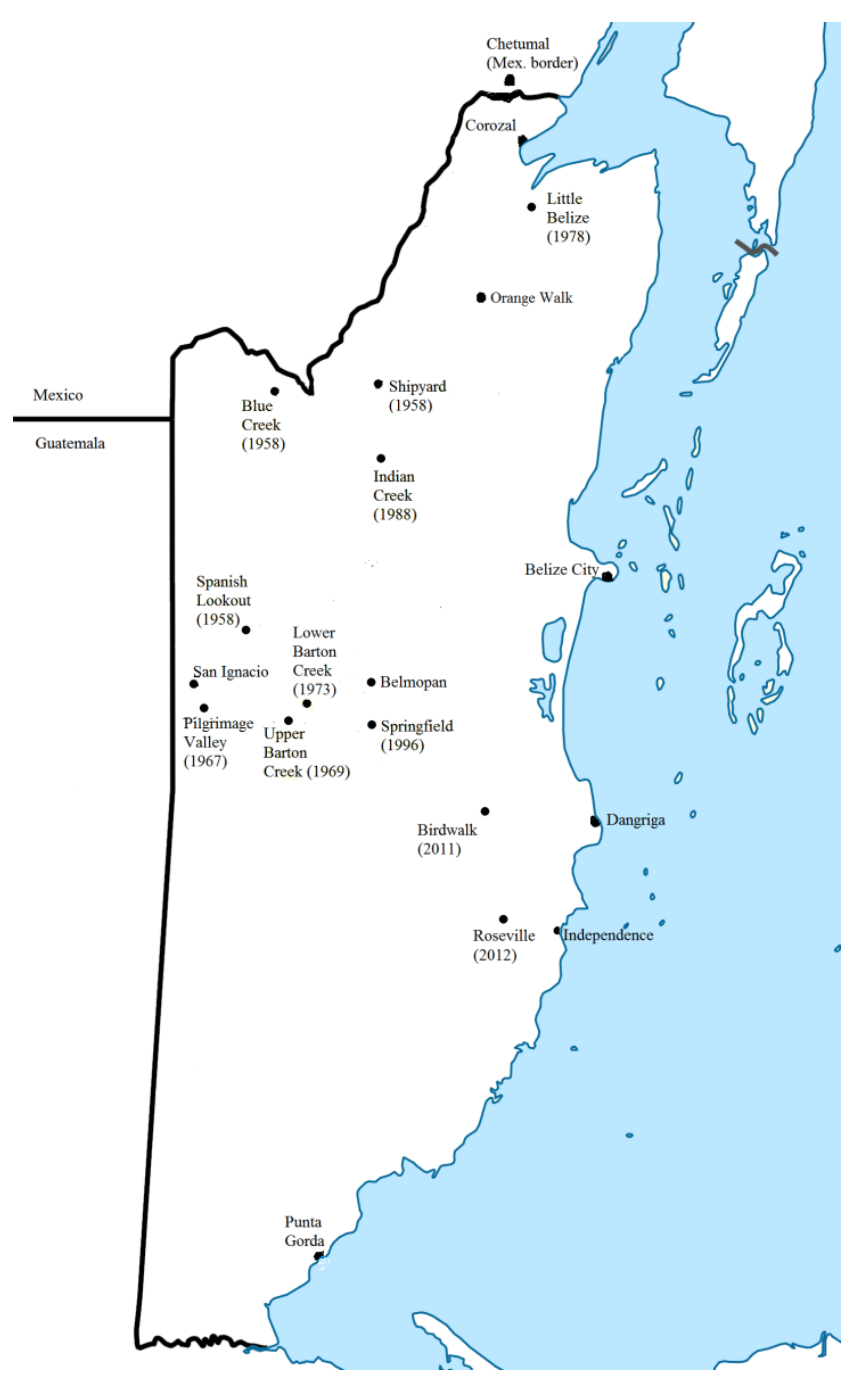

moments from a larger group for religious and moral reasons. Because they arrived after the 1966 immigration condition change, studying the way this community has grown and developed offers one way to understand the ways a community's religious convictions interact with local laws.

As the next section describes, the Hoover Mennonites first settled in Barton Creek, later expanding to Springfield and most recently Bird Walk and Roseville. Figure 1 shows the location and founding year of these settlements. Table 1 lists the different churches and their settlements. As can be seen in Table 1, settlements vary in size. The Hoover settlements are smaller than 400 inhabitants (approximately 35 families), relatively small compared to older settlements such as Shipyard, Little Belize and Spanish Lookout. 
Having now sketched the Belizean context and different ways in which separation (and subsequent migration) occurs among Mennonites, we move to the next section, which provides the concrete historical circumstances in which these separations took place in the case of the Hoover Church.

\section{Belize and the Mennonites: The Early Years (1958-70)}

The bus trip taken by visitors entering Belize today is quite different from the trip made by the first Mennonites settling in Belize. In 1958, several groups of Mennonites (Kleine Gemeinde and Old Colony) from Mexico established their first settlements in Belize, by invitation of the government of British Honduras. To the government, the Mennonite farmers represented reliability, and have since proven to be valuable business partners for the other inhabitants of Belize (Roessingh and Schoonderwoerd 2005).

Instead of entering immediately into a period of stability and growth after their emigration, first-hand accounts describe the first years of the settlements as marked by agricultural setbacks and disagreement. The agricultural difficulties stemmed from the new environment represented by the jungle, the humid climate, and the long periods of rain. Land, after it was deforested, transformed into pools of mud. The description by Gerard Koop, a member of the Spanish Lookout settlement with an interest in history, paints a dramatic picture in his book The Pioneer Years in Belize:

[...] after a weary and tiring journey, they arrived on the southern bank of the Belize River at the present side of Spanish Lookout's southern edge. Neither bridge [nor] ferry awaited them. On the northern bank of the river was a dark and forbidding jungle with its strange noises and smells. Underneath the dense bush, giant snakes and jaguars made their home. The apprehensive settlers may have had thoughts akin to those of the Children of Israel in Numbers 14:3: 'Why did the Lord bring us to this land to allow us to fall by the sword (tropical diseases)? Our wives and children will be taken as plunder. Would it not have been better for us to return to Egypt?' (Koop 1991, vii)

The land also yielded practical frustrations about doing agriculture in a completely new environment. The land in Belize was in many ways the opposite of Mexico.

We had been here for only a few weeks when our settlement foreman became very depressed with the conditions here in British Honduras. With the high expenses of clearing land, building houses, keeping food on the table, with no foreseeable income in the near future, great doubts arose as to whether the settlement and personal success would ever occur. This event had a very negative influence on the new settlers. But new settlers continued to arrive in spite of the spirit of despondency in some homes. (Peter F. Kornelsen in Koop 1991, 24)

With these practical difficulties, conflicts soon arose between the conservative members and those who wanted to implement modernizing processes. As stated before, it is a recurring event in the history of the Mennonites that it is generally the more conservative members of a community who choose to leave when unsolvable disputes arise between groups. This history 
repeated itself in Blue Creek in 1958 and in Spanish Lookout in 1966. The schism in Blue Creek caused a large group of Old Colony Mennonites to leave to Shipyard (Roessingh and Bovenberg 2016). In Spanish Lookout, the schism involved the internal separation in the Kleine Gemeinde Church. The Kleine Gemeinde Mennonites, who held that there should be more room for the use of motorized agricultural equipment, came into conflict with their fellow church members who, according to the passage in Genesis 3:19 "You shall earn your bread by the sweat of your brow" held that processes of labor-saving modernizations conflicted with a basic Biblical principle (Schneider 1990, 88). Thirty conservative members of the Kleine Gemeinde community departed in 1966 from the community where, in their conviction, modernization's wind was blowing too hard. This means that, eight years after their arrival in Spanish Lookout, a first internal schism was a fact. The more traditional group migrated to Paraguay (Schneider 1990, 88).

Another group of conservative Kleine Gemeinde Mennonites from Spanish Lookout followed a different route. This group also disparaged "all engine-based technology and vestiges of the market economy” (Loewen 2006, 178; 1993). At first, this group started a community within the boundaries of Spanish Lookout (Schneider 1990). When this attempt failed after two years, Heinrich Friesen, one of the group who rejected the changes towards modernization within the Spanish Lookout settlement, decided to go in search of a piece of land in the Cayo district, out of the direct sphere of influence of Spanish Lookout.

Around the same time in the U.S.A., in 1966, there had been concern among Old Order Mennonite families about the increasing influence of the United States government on their way of life. By way of an advertisement in The Budget, families desiring a migration were alerted that the prime minister of British Honduras, George Price, had "issued an invitation to farmers to move to British Honduras and take part in the agricultural development of this tropical land.” (Nippert 1994, 24) A group of Stauffer Mennonites in Snyder County, PA, and a mixed group of Amish and Old Order Mennonites in St. Joe, AR, answered this call.

\section{Historical Agreements between Belize and the Mennonites: A Key Difference}

The first main migration of Kleine Gemeinde and Old Colony Mennonites in 1958 was the result of an agreement made on the December 16, 1957 between the government of British Honduras and a delegation of the Quellen Colony in Chihuahua and Durango in northern Mexico (Sawatzky1971; Roessingh and Boersma 2011). In this agreement, British Honduras granted the Mennonites, among other privileges:

the right to run their own Churches and schools, with their own teachers, in their own German language, according to their own religion;

the privilege of affirming with the simple 'yes' or 'no' instead of making oaths in or out of the courts; the right to administer and invest the estates of their own people, especially those of widows and orphans, in their own 'Trust System', called the 'Waisenamt', according to their own rules and regulations; 
exemption from any social security or compulsory system of insurance. (Sawatzky 1971, 335)

In turn the Mennonites agreed, among other things, to do the following:

bring into British Honduras capital investment in cash and kind amounting to five hundred thousand dollar more or less British Honduras currency;

produce food not only for themselves but also for local consumption and for export market. (Sawatzky 1971, 335)

Reasons for inviting the Mennonites in 1957 had been to decrease the economic dependence that the small colony of Belize had on surrounding nations, with its strong reliance on imported "capital, imported food supplies and manufactured goods” (Hidgon 1997, 27; Sutherland 1998). Skilled farmers were therefore required, the government soon decided, in order to render the rough tropical forests fit for cultivation and stock-breeding and to establish a commercial agricultural sector in the country. George Price, who was the Member for Natural Resources of the Government of British Honduras in 1957, stated that:

One reason for encouraging them, was that the Mennonites are good farmers and since Belize had a small population and an excess of land, I thought it would be a good idea to introduce modern techniques of agriculture in our traditional ways. (Shaw 1987, 13)

In the retrospective words of one of the original migrants, reasons for moving were phrased as follows:

Today I think the main reason was that the Almighty God wanted a Christian Church in Belize, yes, a light in the country and a place where He could show His power. (Pete F. Kornelsen in Penner, et al. 2008, 1)

The first migration wave of Mennonites in 1958 received a set of agreement conditions that would not be available to the Mennonites who migrated to British Honduras in 1966. This change of government policy was based on the concern that Mennonite enclaves like Spanish Lookout, Blue Creek, and Shipyard would become too self-sufficient and the consequence could be a more separated position towards the Belizean society. There were also concerns of a growing sense of resentment among the local population (Peedle 1999). One of these changed policy conditions was the "open colony" (Nippert 1994, 25), which meant a government ban on the closed-colony system (the third condition of the original agreement), effectively allowing non-Mennonites to settle among Mennonites and to bid on the same land for sale.

A second condition was the admittance of Belizean school children in the Mennonite school system, which had repercussions on the languages spoken in the classrooms (affecting the first condition of the original agreement). Thus, the Mennonites arriving after the first group faced pressures to be more intricately interwoven with the local society. Or as Nippert (1994) explains it, "Many of the 1958 privileges were [...] granted, but the government wanted to ensure a mix of the colonists with the local population” (25). In practice, the Old Order 
Mennonites kept their settlements small and had to conduct their search for suitable land farther afield as a consequence of the open colony system, once their numbers grew. The next section describes this growth.

\section{The Development of a New Community: Upper Barton Creek}

These new rules would affect the migrants from the U.S.A. who went looking for land in Belize in 1966. One of the main reasons for their migration was in fact a desire for isolation from the world. These families had come from St. Joe, Arkansas, and Snyder County in Pennsylvania. After entering the country of Belize in April 1967, the Mennonites came upon a piece of land which they called Pilgrimage Valley. The variety in church groups that gathered at Pilgrimage Valley is described by Peter Hoover (2018):

The Pilgrimage Valley Community, just south of the large Spanish Lookout Kleine Gemeinde Mennonite Colony, near San Ignacio (Cayo), Belize, got established in 1966 when the extended Albert Stoll and John W. Martin families (Martin no longer living) moved in from St. Joe, Arkansas. Others followed in short order, including minister Jerry Troyer, originally of the Hohenwald Amish group, later of the merged Amish Christian and Titus Hoover groups, plus former members of the Mammoth Springs, Orthodox Mennonite, Muddy Pond, Old Order Mennonite and Amish groups. For a number of years the radical simplicity in lifestyle and high standard of ethics maintained by the settlers in Pilgrimage Valley held the promise of achieving all the Pure Church Movement had hoped to attain. (p. 90)

This unity did not last. Nippert writes how "the hiring of tractors for plowing by some Mennonites, and the close proximity of Santa Elena and San Ignacio prompted some settlers to entertain notions of moving.” (Nippert 1994, 26). Peter Hoover continues,

But by the mid-1970s most of the families had moved or were moving to other locations, mainly to the upper Barton Creek settlement nearby, to Lobelville, Tennessee, or to a new community founded at Finger, Tennessee by Victor Stoll [...] and Harry Wanner in 1975. [...] No organised group remained at Pilgrimage Valley in 2010.

In 1968 two men, John Shirk and Titus Martin, moved out of Pilgrimage Valley with their families. Heinrich Friesen from Spanish Lookout joined them in their search for new land. After a year, the three men purchased an 850-acre plot (Schneider 1990, 89). They named their new settlement Upper Barton Creek, after the river that runs through it. Soon after, they were joined by other families from Spanish Lookout and Pilgrimage Valley. Schneider (1990), notes,

During the years that followed the founding of Upper Barton Creek in 1969, the community, which was originally very small, expanded unexpectedly when a number of Amish and Old Order Mennonites moved to Upper Barton Creek. Both these group had managed to maintain a traditional lifestyle in Belize, cut off to a great extent from the influences of the outside world. [...] [In Upper Barton Creek] the two most important needs of Old Order Mennonites and the Old Order Amish could be satisfied: the isolated situation of Upper Barton Creek was a guarantee that they could maintain the distance to the native population which they so much valued; on the other hand, San Ignacio was 
within relatively easy reach, providing marketing possibilities which were nevertheless a necessity. (p. 90)

The consequences of the land-use agreements with the Belizean government began to appear as well. "Over the next years, local Mayan farmers began to live on the Mennonite-owned land” (Nippert 1994, 33). The open-colony system of the new agreement allowed nonMennonites to purchase land within the Mennonite community. Differences in lifestyle and ideology raised difficulties between the two groups, and most of the Mayan families moved “outside the Mennonite boundary. By 1980, all but one family had moved” (Nippert 1994, 34) away from Upper Barton Creek. Between 1983 and 1985, families from the neighboring community of Lower Barton Creek joined Upper Barton Creek. Originally these families had their roots in the Old Colony Mennonite settlement of Shipyard.

\section{Continued Growth: Fellowship with Hoover Mennonite Churches}

In 1984, the Upper Barton Creek Mennonites started to form a relation of fellowship with the Hoover Mennonites, who were based in Scottsville, Kentucky and trace their roots to Snyder County, PA (Scott 1996; Friesen 1989). The Old Order Mennonites

began to realize they had much the same ideas and interpretations as the Old Order Mennonites of the Noah Hoover Church from Scottsville. As it became more apparent, the two communities started to formulate a plan to formally bring their respective churches together under one affiliation. Elders from Upper Barton Creek made the trek to Kentucky to visit with the Scottsville group and the Scottsville elders did likewise. (Nippert 1994, 48)

In this way, in the course of the 1980s, a denomination new to Belize arose. Connected to the Old Order Mennonites of the Noah Hoover Church in Scottsville, Kentucky, the church in Upper Barton Creek-which consisted of members with a background from the Kleine Gemeinde Church from Spanish Lookout, Old Order Mennonites from the United States, Old Order Amish also from the United States, and Old Colony from Shipyard-became one denomination.

Nippert (1994, 48-49) comments that such affiliations have four important benefits: First of all "it provides the opportunity for members of the two communities [Upper Barton Creek and Scottsville] to share with each their convictions on faith knowing it is received with likemindedness and similar interpretation." Second, "it effectively serves as a physical expansion of both communities. Members of the communities are free to move from one to the other as land pressures mount.” Third, the affiliation also provided an expansion of likeminded Old Order Mennonites. "This is an important consideration in a society which forbids marriage outside the group. The addition of potential marriage partners is most important to the young unmarried Mennonites.” Finally, the affiliation created more financial resources. The two communities have greater possibilities to purchase land for the younger people from their communities, which is in a practical sense a rather important side effect. 
The need for new land, due to large families, was complicated by the circumstances of the agreement with the Belizean government. One consequence was that the Mennonites had to buy pieces of land which were not connected with the borders of Upper Barton Creek. As some families from Lower Barton Creek migrated to the Upper Barton area (Schneider 1990), the Upper Barton colony, already expanding due to its own population growth, was running out of available farming land.

Quite simply, there is nowhere for Upper Barton Creek to expand, the occasional small parcel notwithstanding. With so many youth coming into age and young couples in need of land, it became necessary to purchase another large tract. (Nippert 1994, 37)

In 1996 this resulted in the creation of a new settlement which was called Springfield, towards the Belizean capital of Belmopan. In a similar move in 2011, the settlement of Bird Walk was established in the Cayo district, and, in 2012, the foundation of Roseville in the Stann Creek district was accomplished. They are all Hoover Church communities, small settlements away from the highways connected by family ties. With settlements spread across different districts, one might say that the expansion occurred under the shadow of separation. The Old Order Mennonites sought separation from the world, but the way they have had to expand their possibilities through buying land on different places separates the community into different settlements. However, the settlements remain connected; one way to see this is to observe resemblances and reciprocal ties in their current way of life.

\section{Upper Barton Creek after 47 Years}

Nowadays, Upper Barton Creek community still exists but has lost something of its remote location. It is close to a recently popularized tourist attraction referred to as the Barton Creek Caves. The dusty, bumpy road to the Caves demonstrates the changes in the way this road is used, showing tracks of motor car tires. Small buses with tourists drive through the settlement and, because of the way the Mennonites are dressed and the way the stories about these people pass through the tourist guidebooks, the cameras are put on sharp to take a nostalgic picture of the past. The inhabitants themselves greet these visitors with considerably less enthusiasm. The proximity of this tourist attraction makes the separation from the world unfortunately not precisely as the Old Order Mennonites of Upper Barton Creek had hoped for at its founding.

What these cameras capture is not easily recognized as a community; houses, reported to support 380 inhabitants, stand far apart, and high leafy ridges block the lay-out of the settlement from view (Statistical Institute of Belize 2013). In the literature, church buildings of the Hoover Mennonites are generally referred to as meetinghouses (Oberholtzer 2017; Scott 1996). The meetinghouse in Upper Barton Creek, which resembles the Springfield meetinghouse (Figure 2), doubles as a schoolhouse. 


\section{Figure 2: Upper Barton Creek (Left) and Springfield (Right) Meetinghouses}

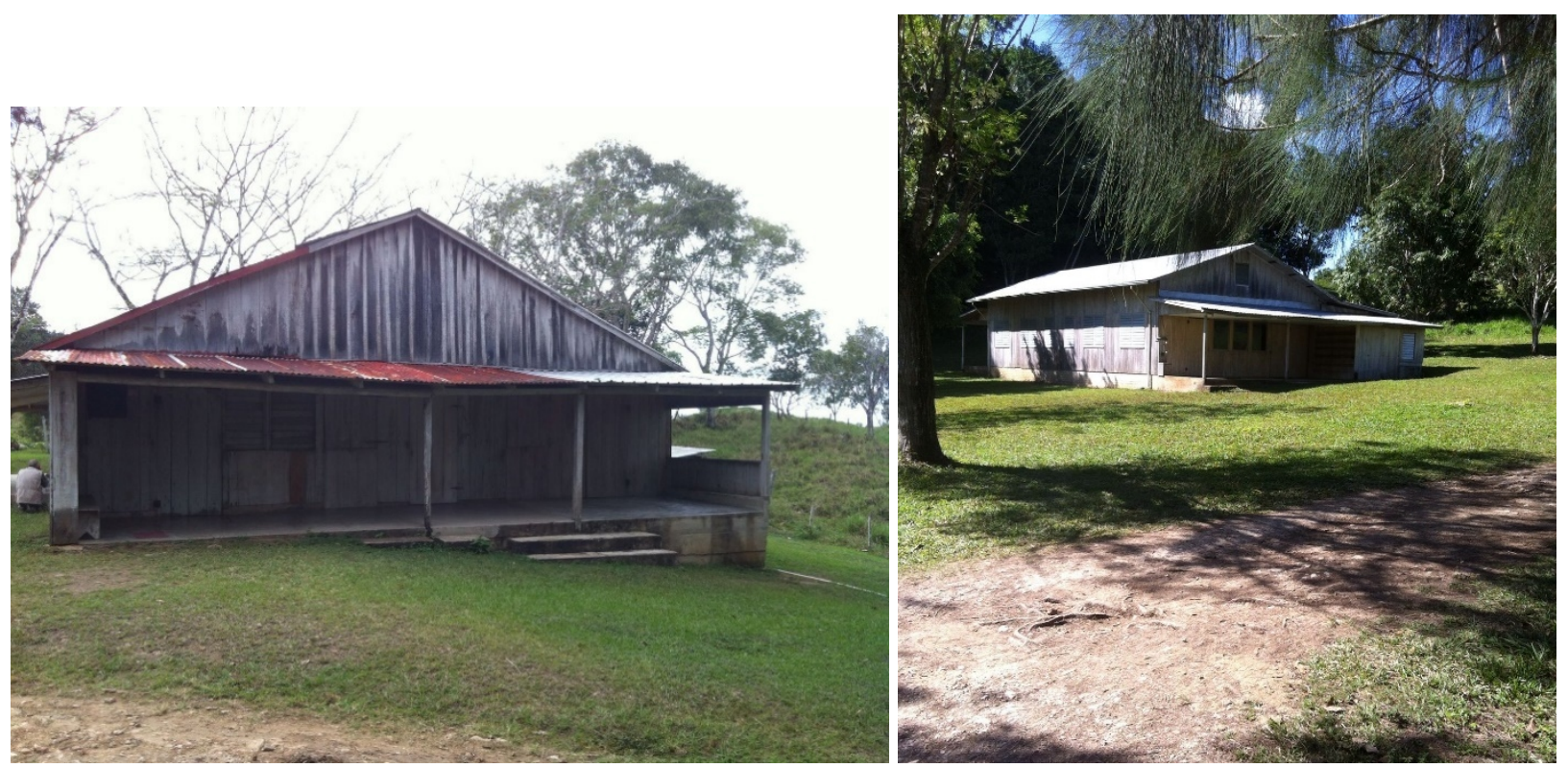

Photos: Carel Roessingh

\section{First Separation: Springfield}

Springfield is a small settlement, founded in response to a land shortage in the Barton Creek area. The road leading to the Mennonite colony branches off of the Hummingbird highway, which runs from Belmopan to Dangriga. The road is unpaved and bumpy, and in the rainy season it is even more difficult to drive than in the dry season. The road lurches through Springfield until it stops at the last farm, where the jungle arises (Roessingh 2013). The Springfield settlement counts approximately 270 inhabitants (Statistical Institute of Belize 2013). The inhabitants of Springfield and Upper Barton Creek do not allow the use of modern technology or electricity. Horsepower drives the sawmill and water powers a turbine in Upper Barton Creek and Springfield, which is owned by the people of the community. Work on the fields is done with an oxen team or horses. All transportation is done by horse-drawn wagons, and their houses are modest. Their farms, which lie scattered between the hillsides of the Maya Mountains over an area of roughly 2,000 acres, appear more like horticultural lands than large farms (Lentjes, et al. 2009).

The communities in Upper Barton Creek and Springfield share a common way of life, which is reflected in their agricultural and horticultural business practices. Although some people in Upper Barton Creek and Springfield engage in small-scale businesses in order to make a living, or to supplement their income, most families in the community make their living through small-scale farming. It is mainly the men and boys who work the land, although women and girls do help during planting and harvest (Lentjes, et al. 2009). Products such as cheese, honey, fruit, lettuce, carrots, potatoes, melons, and sugarcane are sold at the market building in the settlement, or at the market in Belmopan or San Ignacio. Like the Upper Barton Creek Mennonites, the 
Springfield Mennonites constructed a market building in the center of their settlement near the sawmill and the meetinghouse. On the bi-weekly market days, this usually isolated settlement bustles with activity. Vans and pick-ups drive in and out while the Springfield Mennonites are busy packing and selling products. The three "market workers" coordinate the selling of vegetables and farming products to wholesale buyers from outside the settlement. At the turn to Springfield on the Hummingbird Highway, an eye-catching billboard advertises their range of trees for sale (Figure 3). At the Belizean market, these fruit trees are known for their high quality and are therefore much in demand.

\section{Figure 3: Sign Indicating the Location of the Springfield Settlement along the Hummingbird Highway}

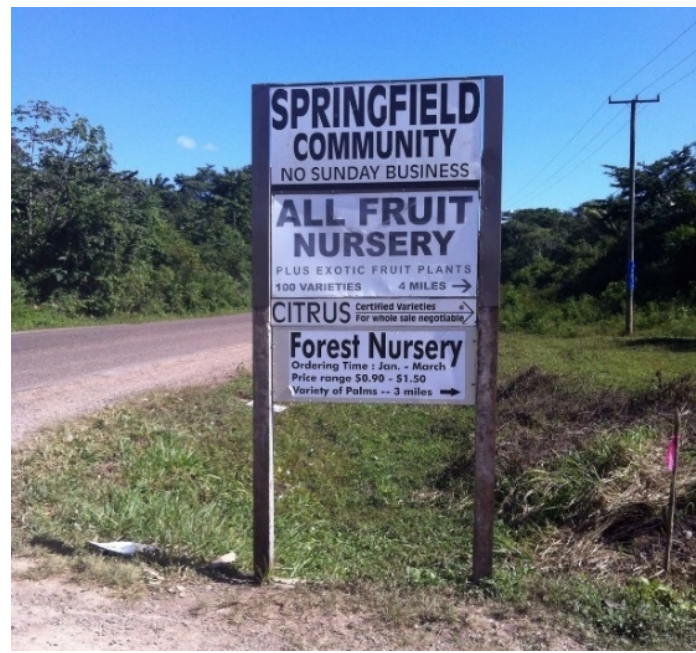

Photo: Carel Roessingh

\section{Distance and Connection between Barton Creek and Springfield}

Family ties continue to connect the Old Order Mennonites of the communities in the U.S.A., Upper Barton Creek, Springfield, and, nowadays, Bird Walk and Roseville. Lentjes $(2004,36)$ gives a picture of the distance to be crossed when people from the different Old Order settlements set out to visit one another:

Early this morning I leave with Gertruda Harder to go to Ginnerich Manroe, so that I can catch a ride with Dina and Thomas Penner to Upper Barton. They had initially told me that we would travel through the forest (jungle), [which is] about five hour's ride, but when we arrive at Manroe, it turns out that we will be taking the [paved] road because it has rained a lot. This ride takes nine hours. The only thing I have with me is water. After five hours we encounter Abram Fehr and his family. They are returning to Springfield from Upper Barton Creek. We rest for an hour, so that the horses can rest and eat. We also rest and eat. Dina gives me some food. (Field notes November 28, 2002)

Although this field note entry gives a picture of the geographical separation of the different settlements, and the effort required to travel between them (the distance is 
approximately 45 kilometers), it is important to keep in mind that such hardship is not necessarily something to be avoided by the Old Order Mennonites. It is perhaps a small price to pay to maintain their separation from the world. Although the distance may seem like a handicap to outsiders, the Old Order Mennonites do not see this as a problem, habituated as they are to traveling long distances to kindred denominations in North America.

\section{Conclusion and Reflection}

Histories of Mennonite migration often stress the central role of religious difference and unity in the formation of new settlements, with the most conservative members of a community as the first to seek relocation. In Belize, too, religious difference has at times been a decisive force in the creation of new communities and settlements. We see in the case of the Hoover Mennonites, however, a community that agrees religiously but lives apart. We have tried to account for this migration pattern by examining the Old Order commitment to separation from the world, their preference for smaller settlements, and the change of laws related to land use enacted by the Belizean government. Today, Old Order Mennonites in the Springfield settlement say that, aware as they were of the changed government conditions, that this was not the main driver behind their land purchase decisions. They describe how quality of the land ranks higher in importance in selecting a plot to buy, as well as the price, and a preference to stay under 35 families. It is important to consider all of these influences when trying to understand the development of the Hoover community. We make a distinction between Mennonite groups who arrived in Belize before 1966 — who settled in large, independent enclaves with an internal system of governance and schooling - and those who settled after the government of Belize had adopted changed conditions for incoming migrants, limiting their capability to buy contiguous land. We argue that this change has repercussions on how the Old Order Mennonites organized their need for land and continue to do so today.

The Old Order Mennonites seem to be divided not in their religious bond but in the geographical possibilities to be one community. In the rainy season, a buggy ride from Springfield to Upper Barton Creek can take about nine hours. The latest settlement of Roseville is not in the range of driving with horse and buggy. A tale of the expansion of the Old Order Mennonites in Belize is thus a tale of a double separation, of moving away from those considered worldly and away from one's own community. One conclusion we can make is that the internal cohesion within the community and the separation of the worldly society is under a particular kind of pressure. Nonetheless, the Old Order Mennonites, just as the other Mennonite denominations, are a stable presence in the economy of Belize. This leads us to believe that they have found a way to maintain their way of life in the multi-ethnic country. The change in rules merely changed the way in which the Mennonites seek separation; now they divide their community geographically, presenting practical difficulties to the members of the dispersed settlements. 


\section{Endnote}

${ }^{1}$ For ease of reference, we will be referring to this group as the Hoover Mennonites throughout this article.

\section{References}

Anderson, Cory. 2013. "Who Are the Plain Anabaptist? What Are the Plain Anabaptists?" Journal of Amish and Plain Anabaptist Studies 1(1):26-71. https://doi.org/10.18061/1811/54897

Anderson, Cory, and Jennifer Anderson. 2016. "The Amish Settlement in Honduras, 19681978: A (Half) Failed Attempt to Develop an Amish Understanding of Mission.” Journal of Amish and Plain Anabaptist Studies 4(1):1-50. https://doi.org/10.18061/1811/78020

Bolland, O. Nigel. 1986. Belize: A New Nation in Central America. Boulder, CO: Westview Press.

Everitt, John. 1983. “Mennonites in Belize.” Journal of Cultural Geography 3(2):82-93. https://doi.org/10.1080/08873638309478597

Friesen, Heinrich. 1989. “Upper Barton Creek Colony (Belize).” Global Anabaptist Mennonite Encyclopedia Online. Retrieved 24 April, 2017 (http://gameo.org/index.php/ title=upper_barton_creek_colony_belize)

Higdon, Francis. 1997. Farm Diversification and Specialization: The Adaptation of Mennonite Households in Spanish Lookout, Belize. Ph.D. dissertation. Pittsburgh, PA: University of Pittsburgh.

Hoover, Peter. 2018. “Pure Church Movement.” Journal of Amish and Plain Anabaptist Studies 6(1):73-99.

Koop, Gerard. 1991. Pioneer Years in Belize. Belmopan, Belize: Published by G.S. Koop.

Lentjes, Lobke. 2004. In de wachtkamer van het geluk: Een studie naar de invloed van religie op ondernemingen van de Mennonieten in Springfield. M.A. Thesis. Amsterdam, The Netherlands: Vrije Universiteit Amsterdam.

Lentjes, Lobke, Tanja Plasil, and Carel Roessingh. 2009. “The Heavenly Valley: Small Scale Farmers and Entrepreneurs in Springfield.” Pp. 149-69 in Between Horse \& Buggy and Four-Wheel Drive: Change and Diversity among Mennonite Settlements in Belize, Central America, edited by Carel Roessingh and Tanja Plasil. Amsterdam, The Netherlands: VU University Press. 
Loewen, Royden. 1993. Family, Church and Market: A Mennonite community in the Old and New Worlds, 1850-1930. Urbana, Il: University of Illinois Press.

Loewen, Royden. 2006. Diaspora in the Countryside: Two Mennonite Communities and MidTwentieth-Century Rural Disjuncture. Toronto, ON: University of Toronto Press. https://doi.org/10.3138/9781442627871

Luthy, David. 2007 [1997]. Why Some Amish Communities Fail: Extinct settlements, 19612007. Aylmer, ON: Pathway Publishers.

Nippert, Dale. 1994. Agricultural Colonization: The Mennonites of Upper Barton Creek, Belize. M.A. Thesis. Memphis, TN: The University of Memphis.

Oberholzer, Beth. 2017. Plain Meetinghouses. Lancaster County Old Order Mennonites Gather to Worship. Atglen, PA: Schiffer Publishing, Ltd.

Peedle, Ian. 1999. Belize in Focus: A Guide to the People, Politics, and Culture. New York, NY: Interlink Books. https://doi.org/10.3362/9781909013025

Penner, Heinrich, John Reimer, and Leonard Reimer (eds.) 2008. Spanish Lookout Since 1958: Progress in Action. Benque Viejo, Belize, C.A: BRC Printing.

Plasil, Tanja, and Carel Roessingh. 2006. "Food and the Community: The Role of Sharing a Meal among the Mennonites of Shipyard, Belize.” Belizean Studies 28(1):42-56.

Roessingh, Carel. 2007. "Mennonite Communities in Belize.” International Journal of Business and Globalisation 1(1):107-24. https://doi.org/10.1504/IJBG.2007.013722

Roessingh, Carel. 2013. "Research Note: Small-Scale Farmers in Springfield Colony, Belize.” The Mennonite Quarterly Review 87(4):574-83.

Roessingh, Carel, and Kees Boersma. 2011. “'We Are Growing Belize’: Modernisation and Organisational Change in the Mennonite Settlement of Spanish Lookout, Belize.” International Journal of Entrepreneurship and Small Business 14(2):171-89. https://doi.org/10.1504/IJESB.2011.042718

Roessingh, Carel, and Amber Schoonderwoerd. 2005. “Traditional Farmers or Modern Businessmen? Religious Differentiation and Entrepreneurship in a Kleine Gemeinde Mennonite Community in Belize.” Journal of Developmental Entrepreneurship 10(1):65-77. https://doi.org/10.1142/S1084946705000069

Roessingh, Carel, and Tanja Plasil (eds.). 2009. Between Horse \& Buggy and Four-Wheel Drive: Change and Diversity among Mennonite Settlements in Belize, Central America. Amsterdam, The Netherlands: VU University Press. 
Roessingh, Carel, and Daniëlle Bovenberg. 2016. ““No Sunday Business’: Navigating Religious Rules and Business Opportunities in Shipyard Mennonite Settlement, Belize.” Journal of Amish and Plain Anabaptist Studies 4(2):133-48. https://doi.org/10.18061/1811/79936

Sawatzky, Harry. 1971. They Sought a Country: Mennonite Colonization in Mexico. Berkeley, CA: University of California Press.

Schneider, Helmut. 1990. Tradition und Veränderung in Belize (Mittelamerika): Ein soziologischer Vergleich der Gemeinden San Ignacio und Upper Barton Creek. Diploma Thesis. Berlin, Germany: Lateinamerika-Institut der Freien Universität Berlin.

Schrock, Fredrick. 2001. The Amish Christian Church: Its History and Legacy. Altamont, TN: Ambassador Publishers.

Scott, Stephen. 1996. An Introduction to Old Order and Conservative Mennonite Groups. Intercourse, PA: Good Books.

Shaw, Marjorie. 1987. Mennonites in Belize: A Case Study of the Spanish Lookout Community. Bachelor Thesis. Mona, Kingston, Jamaica: University of the West Indies.

Statistical Institute of Belize (2013). Belize Population and Housing Census, Country Report 2010. Belmopan, Belize, C.A. Retrieved on 20 March, 2017 (http://www.sib.org.bz/statistcs/population.)

Sutherland, Anne. 1998. The Making of Belize. Globalization in the margins. Westport, CT: Bergin \& Garvey. 